\title{
LATE PALAEOZOIC MAGMATISM IN THE BASEMENT ROCKS SOUTHWEST OF MT. OLYMPOS, CENTRAL PELAGONIAN ZONE, GREECE: REMNANTS OF A PERMO-CARBONIFEROUS MAGMATIC ARC T. REISCHMANN ${ }^{1}$, D. K. KOSTOPOULOS ${ }^{2}$, S. $_{\text {LOOS }}^{1}$, B. ANDERS ${ }^{1}$, A. AVGERINAS ${ }^{2}$ \& S. A. SKLAVOUNOS
}

\section{ABSTRACT}

We dated basement rocks from several localities southwest of Mt. Olympos, as well as from a locality near the top of the mountain using the single zircon $\mathrm{Pb} / \mathrm{Pb}$ evaporation technique. For the samples southwest of the mountain, the ages obtained range from ca. 280 to $290 \mathrm{Ma}$, with only a few zircon grains being around $300 \mathrm{Ma}$. By contrast, the sample from near the top of the mountain appears to be slightly younger, with ca. $270 \mathrm{Ma}$. These ages imply that the granitoids crystallized during Late Carboniferous - Early Permian times, and are therefore younger than the basement gneisses of other regions of the Pelagonian zone, which yielded zircon ages of around $300 \mathrm{Ma}$ (e.g. Yarwood \& Aftalion 1976, Mountrakis 1983, De Bono 1998, Engel \& Reischmann 2001). However, the ages obtained in the present study are identical, within error, to the muscovite Ar-Ar cooling ages from Mt. Ossa (Lips 1998). Our geochronological data show that the magmatic evolution for this part of the basement of the Pelagonian Zone lasted at least $30 \mathrm{Ma}$.

KEY WORDS: Pelagonian Zone, Mt. Olympos, Greece, pre-Alpine basement, zircon geochronology.

\section{INTRODUCTION - GEOLOGICAL BACKGROUND}

The area occupied by what is known as the Pelagonian Zone is composed of several tectonic units (see Avgerinas 1999 for a recent summary and compilation of reference). The structurally lowermost unit is the neritic carbonate unit (Olympos unit), outcropping in the areas of Olympos, Ossa, Rizomata, and Krania (Fig. 1). The Olympos unit is overlain by the intermediate blueschist unit (Ambelakia unit), which, in turn, is overlain by the composite Pelagonian nappe.

In his pioneering work, Godfriaux (1968) maintained that the neritic carbonate unit represents pieces of the carbonate platform of the Adriatic-Apulian promontory of Gondwana (i.e. External Hellenides), now exposed in the form of tectonic windows amidst the Pelagonian Zone, an interpretation adopted by many subsequent workers (e.g. Schermer 1993). Schmitt (1983), however, was the first to oppose the widely accepted view of Godfriaux above, and proposed that the neritic carbonate unit palaeogeographically belongs to the Internal Hellenides (see also Vergily \& Mercier, 1990).

The Pelagonian nappe comprises (Kilias \& Mountrakis 1989):

i) The pre-Alpine crystalline and magmatic masses of Voras, Vernon and Pieria-Kamvounia mountains as well as those outcropping further to the south (E. Mt. Othris, S. Mt. Pelion, Skiathos Isl., and N. Evia Isl.),

ii) The Permo-Triassic volcano-sedimentary series and the Triassic-Jurassic carbonates which are non- to only weakly metamorphosed at the western margin and more intensely metamorphosed at the eastern margin of the Pelagonian nappe,

iii) The ophiolites, characterized by Late Jurassic - Early Cretaceous deformation, and

iv) The transgressive Cretaceous limestones that pass upwards into Palaeocene flysch.

Strong tectonism during the Early Cretaceous and Tertiary brought about multiple zones of mylonitization and imbrication, and thrusting of the units from east to west. Granites, orthogneisses and metapelites are predominant amongst the pre-Alpine lithologies and constitute the crystalline basement of the Pelagonian Zone. The origin of this pre-Alpine basement, however, is poorly constrained due to the lack of reliable age determinations. A Carboniferous zircon U-Pb age of $302 \pm 5$ Ma was reported from the Kastoria area, NW

1. Institut für Geowissenschaften, Johannes Gutenberg-Universität, Becherweg 21, 55099, Mainz, Germany \& Max-Planck-Institut für Chemie, Becherweg 27, 55020, Mainz, Germany. E-mail: Thomas.Reischmann@uni-mainz.de; Tel.: +49-6131-3922859.

2. School of Geology, Department of Mineralogy, Petrology and Economic Geology, Aristotle University, Thessaloniki, 54006, Greece. Email: mimis@geo.auth.gr; Tel.: +30-31-998142; Fax: +30-31-998568. 
Pelagonian Zone (Mountrakis 1983). A similar zircon U-Pb age of 302.4 +5/-15 Ma was published by Yarwood and Aftalion (1976) for granodiorites from the Kataphygion area, Pieria mountains, ' $20 \mathrm{~km}$ NW of Mt. Olympos, central Pelagonian Zone (Fig. 1). De Bono (1998) measured zircon U-Pb ages in the range 308-320 Ma for granitic orthogneisses from NW and central Evia Island. Engel \& Reischmann $(1998,2001)$ and Reischmann (1998) have also confirmed zircon Pb-Pb ages of ca. 300-315 Ma in the Cyclades (Attic-Cycladic Massif). It is therefore evident that Carboniferous magmatic activity was widespread over large parts of mainland Greece and the Aegean region. This Carboniferous magmatism may also have been responsible for the formation of crystalline massifs in the Sakarya continent, NW Turkey, where similar zircon Pb-Pb ages (313-293 Ma) have been reported (Фzmen \& Reischmann 1999).

In this contribution we will focus on the geochronology of basement rocks in the Mt. Olympos region by single zircon $\mathrm{Pb} / \mathrm{Pb}$ dating. The aim is to understand the origin of these pre-Alpine basement occurrences and to establish possible relations with other parts of the Pelagonian Zone.

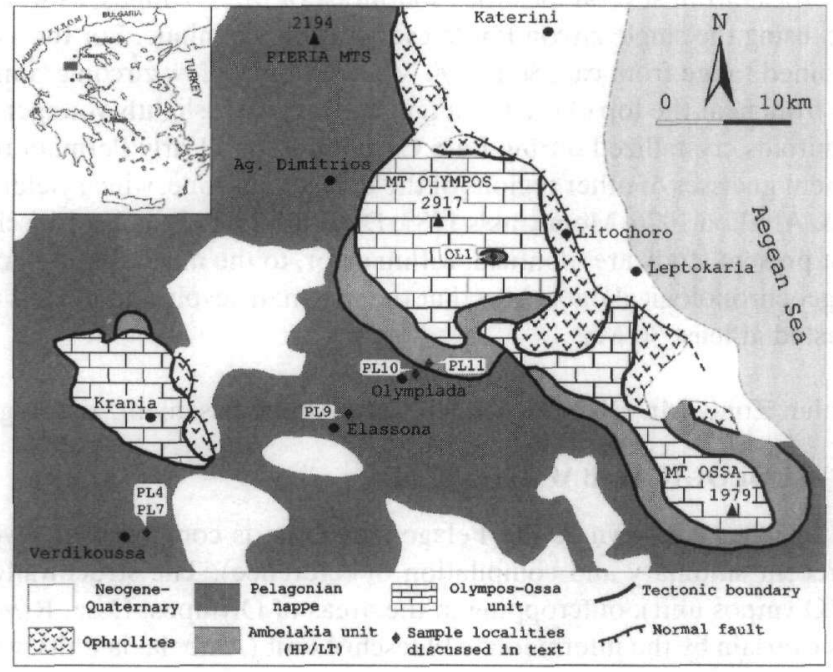

Figure 1. Simplified geological map of the central Pelagonian Zone, showing sample locations (modified after Kilias 1995).

\section{ANALYTICAL METHODS}

The samples, each weighing ca. $12 \mathrm{~kg}$, were crushed using jaw crushers and a roller mill to produce powders of $<0.50 \mathrm{~mm}$ particle size. Firstly, heavy minerals were concentrated using a Wilfley Table. Further concentration of the non-magnetic heavy minerals was achieved using a magnetic separator and heavy liquids. Final hand picking was done under a binocular microscope where zircons suitable for geochronological analysis were selected. Only zircon grains without visible core or inclusions were chosen.

In this study we used the $\mathrm{Pb} / \mathrm{Pb}$ single-grain evaporation method (Kober 1987) that involves the repeated evaporation and deposition of $\mathrm{Pb}$ from chemically untreated zircons in a double-filament arrangement. The mass-spectrometer used for this analysis was a Finnigan MAT 261 at the Max-Planck-Institut fór Chemie in Mainz, Germany. The isotope ratios were measured on a secondary electron multiplier.

The ${ }^{207} \mathrm{~Pb} /{ }^{206} \mathrm{~Pb}$ ratios measured were corrected for common $\mathrm{Pb}$ after Stacey \& Kramers (1975). No correction was made for mass fractionation, which is significantly less than the uncertainty of the isotope ratios measured (Kober 1987). More details of the method are given in Reischmann \& Anthes (1996). The age calculations were performed using the decay constants of Steiger \& Joger (1977). Errors for the individual zircon measurements are reported as 2 -sigma of the mean. The mean ages of the samples are given with standard. The analytical data are listed in Table 1.

\section{GEOCHRONOLOGICAL RESULTS}

Sample PL-4 was taken from a road cut between Elassona and Verdikoussa village, $6 \mathrm{~km}$ east of the latter locality (Fig. 1). The sample is a mainly medium-grained, undeformed, mesocratic granitic rock. It contains 
PI -4:

$\begin{array}{lllllrllll}\text { A } & 350 & \text { pink } & \text { euhedral } & \text { clear } & 134 & 0.051981 & 0.000058 & \mathbf{2 8 4 . 6} & 2.6 \\ \text { B } & 300 & \text { pink } & \text { euhedral } & \text { rel. turbid } & 119 & 0.052044 & 0.000072 & \mathbf{2 8 7 . 4} & 3.2 \\ \text { C } & 300 & \text { pink } & \text { euhedral } & \text { clear } & 129 & 0.051983 & 0.000058 & \mathbf{2 8 4 . 7} & 2.6 \\ \text { D } & 250 & \text { pink } & \text { euhedral } & \text { clear } & 68 & 0.052032 & 0.000123 & \mathbf{2 8 6 . 8} & 5.4 \\ \text { E } & 300 & \text { pink } & \text { euhedral } & \text { clear } & 101 & 0.051942 & 0.000085 & \mathbf{2 8 2 . 9} & 3.7 \\ \text { F } & 280 & \text { pink } & \text { euhedral } & \text { clear } & 67 & 0.051778 & 0.000099 & \mathbf{2 7 5 . 6} & 4.4 \\ \text { G } & 300 & \text { pink } & \text { euhedral } & \text { rel. turbid } & 167 & 0.052085 & 0.000066 & \mathbf{2 8 9 . 2} & 2.9 \\ \text { H } & 250 & \text { pink } & \text { fragment } & \text { clear } & 169 & 0.051872 & 0.000051 & \mathbf{2 7 9 . 8} & 2.3 \\ \text { I } & 250 & \text { yellow } & \text { euhedral } & \text { rel. clear } & 51 & 0.051912 & 0.000100 & \mathbf{2 8 1 . 5} & 4.5 \\ \text { J } & 230 & \text { yellow } & \text { fragment } & \text { rel. turbid } & 59 & 0.051948 & 0.000145 & \mathbf{2 8 3 . 1} & 6.4 \\ \text { mean } & & & & & & & & \mathbf{2 8 3 . 6} & 4.0\end{array}$

\section{PI -7:}

\begin{tabular}{|c|c|c|c|c|c|c|c|c|}
\hline A & 450 & pink & euhedral & rel. turbid & 197 & 0.052060 & 0.000043 & 288.1 \\
\hline B & 250 & pink & euhedral & rel. clear & 92 & 0.052020 & 0.000137 & 286.3 \\
\hline c & 350 & yellow & euhedral & turbid & 96 & 0.052439 & 0.000149 & 304.6 \\
\hline D & 420 & pink & euhedral & turbid & 99 & 0.052360 & 0.000054 & 301.2 \\
\hline$E$ & 380 & pink & euhedral & rel. clear & 133 & 0.05188 & 0.000051 & 280.1 \\
\hline $\mathrm{F}$ & 300 & pink & fragment & turbid & 177 & 0.053192 & 0.000057 & 337.0 \\
\hline $\mathrm{H}$ & 290 & yellow & fragment & turbid & 147 & 0.051365 & 0.00012 & 257.3 \\
\hline I & 330 & yellow & euhedral & turbid & 137 & 0.054078 & 0.000088 & 374.4 \\
\hline \multicolumn{8}{|c|}{ mean of $A, B, E$ : } & 284.8 \\
\hline \multicolumn{8}{|c|}{ mean of C, D: } & 302.9 \\
\hline
\end{tabular}

PI -9:

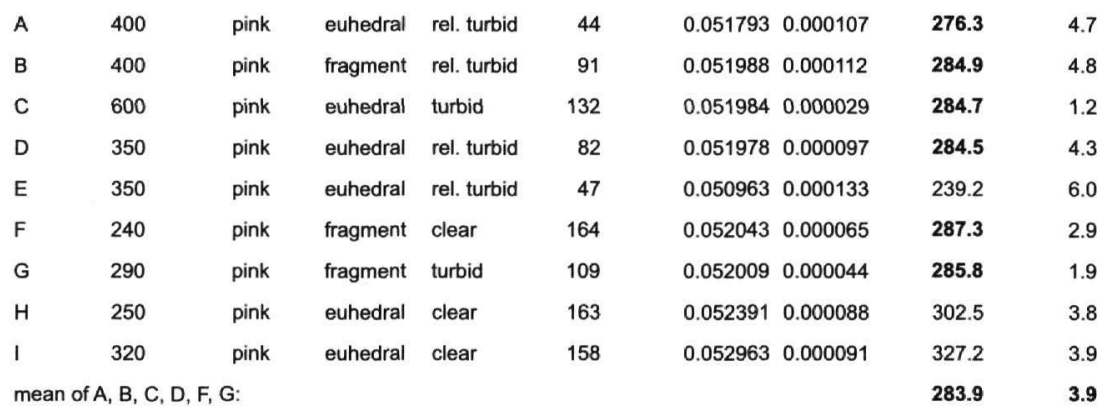

PI -10:

$\begin{array}{llllllllll}\text { A } & 300 & \text { pink } & \text { euhedral } & \text { rel. turbid } & 26 & 0.05196 & 0.00023 & 283.7 & 9.9 \\ \text { B } & 300 & \text { pink } & \text { euhedral } & \text { rel. turbid } & 60 & 0.049543 & 0.000115 & 174.0 & 5.4 \\ \text { C } & 300 & \text { pink } & \text { euhedral } & \text { rel. turbid } & 74 & 0.051934 & 0.000111 & 282.5 & 4.9 \\ \text { D } & 400 & \text { pink } & \text { euhedral } & \text { turbid } & 139 & 0.052003 & 0.000035 & 285.6 & 1.5 \\ \text { E } & 250 & \text { pink } & \text { euhedral } & \text { trüb } & 105 & 0.051701 & 0.000049 & 272.2 & 2.2 \\ \text { F } & 280 & \text { pink } & \text { euhedral } & \text { rel. turbid } & 169 & 0.052143 & 0.000033 & 291.7 & 1.4 \\ \text { G } & 250 & \text { pink } & \text { euhedral } & \text { clear } & 152 & 0.052777 & 0.000061 & 319.2 & 2.6 \\ \text { H } & 410 & \text { pink } & \text { euhedral } & \text { rel. clear } & 54 & 0.052895 & 0.000278 & 324.3 & 12 \\ \text { mean of A, C, D, E, F: } & & & & & & & & & \end{array}$


PI -11:

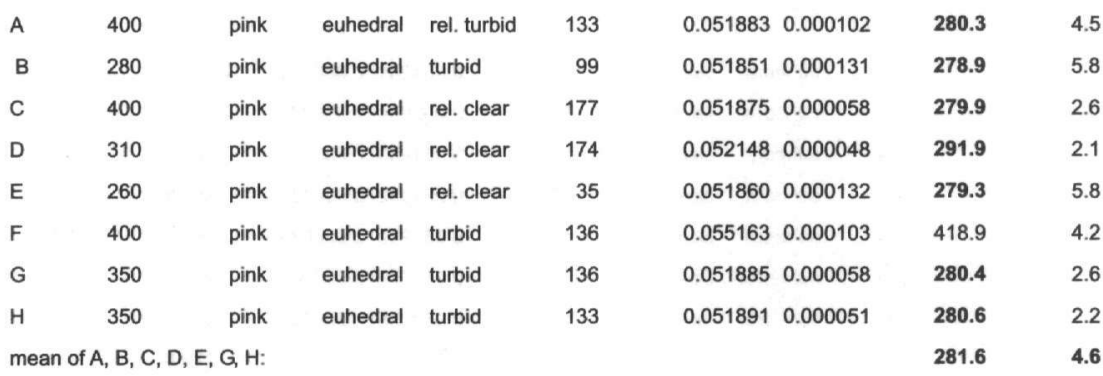

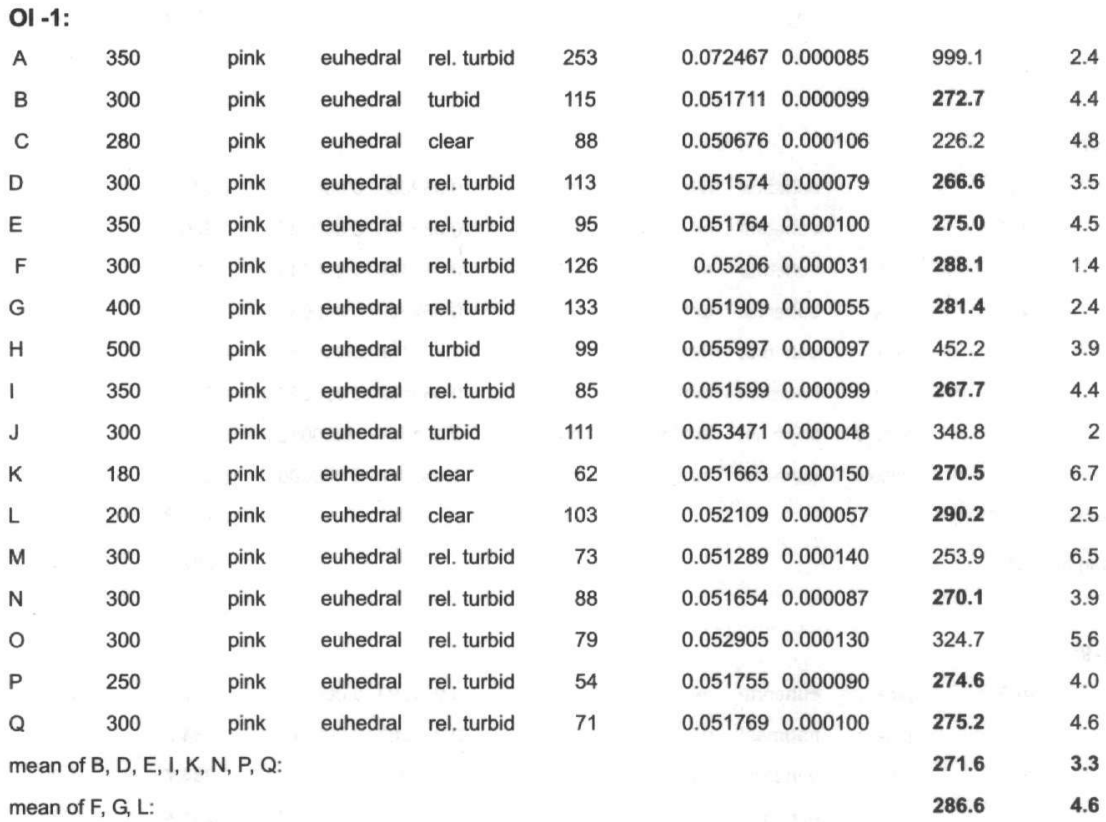

Table 1. Results of single evaporation analyses

quartz, feldspars and biotite with some K-feldspar phenocrysts reaching $2 \mathrm{~cm}$ in size. We consider this rock to belong to the Verdikoussa granite, which according to Pe-Piper et al. (1993a) intruded Pelagonian basement gneisses. However, we found a gradational contact between the gneisses and the granite, and no clear intrusive relationship between the two rock types. This indicates that the granite is an undeformed part of the gneisses.

The zircons of this granite are euhedral, pinkish in colour and mainly clear. Their length is up to $0.4 \mathrm{~mm}$ and they have a bi-pyramidal, long-prismatic morphology. Some measurements were performed on 0.3-0.4 mm fragments of originally even longer zircon grains. The ages obtained for this sample range from 275.6 Ma to 289.2 Ma. The zircon population appears to be rather homogeneous as far as colour, shape, and ages are concerned. Most of the grains yielded ages that cluster around 283.6 $\pm 4.0 \mathrm{Ma}$ (Fig. 4), which is suggested to be the intrusion age of the granite.

Sample PL-7 was taken from a locality $2.5 \mathrm{~km}$ east of sample PL-4 (Fig. 1). This sample is a mediumgrained, porphyritic, weakly-deformed granite. The mineral assemblage is quartz, K-feldspar, plagioclase and biotite. This sample is very similar to PL-4 except for its slight deformation. It shows transitional contacts with its neighbouring granitic gneisses, which are strongly deformed. Once again no evidence for an intrusive relationship between granite and gneisses was observed. According to the geological map of Greece (IGME, 1983) this sampling site belongs to the basement gneisses.

The zircons of this sample are long-prismatic, euhedral, and up to $0.450 \mathrm{~mm}$ in size. The grains are predominantly clear, but turbid grains were also found. They are mainly pink, though yellow or brownish grains can also 
be seen. The zircons of this sample yield ages between 257.3 Ma and 374.4 Ma. There seem to be two populations, one at ca. 302.9 Ma, and the other at 284.8 Ma. The younger age of $284.8 \pm 4.2 \mathrm{Ma}$ is taken here as the intrusion age. The grains that yielded the ages of $374.4 \mathrm{Ma}$ and 337.0 Ma are interpreted as inherited grains, or as composite grains reflecting a mixed age between the $284.8 \mathrm{Ma}$ intrusive event and an unknown ancient source. The 302.9 Ma age is obviously also an intrusive age and might be interpreted as the crystallization of an early Pelagonian pluton that was intruded by the younger $284.8 \mathrm{Ma}$ granite.

Sample PL-9 was taken ca. $12 \mathrm{~km}$ NE of Elassona, close to the village of Olympiada (Fig. 1). This deformed granite displays a pervasive foliation, but the original igneous texture is well preserved. Quartz, feldspars and biotite are the major mineral phases. The slightly greenish colour of the rock is caused by the formation of
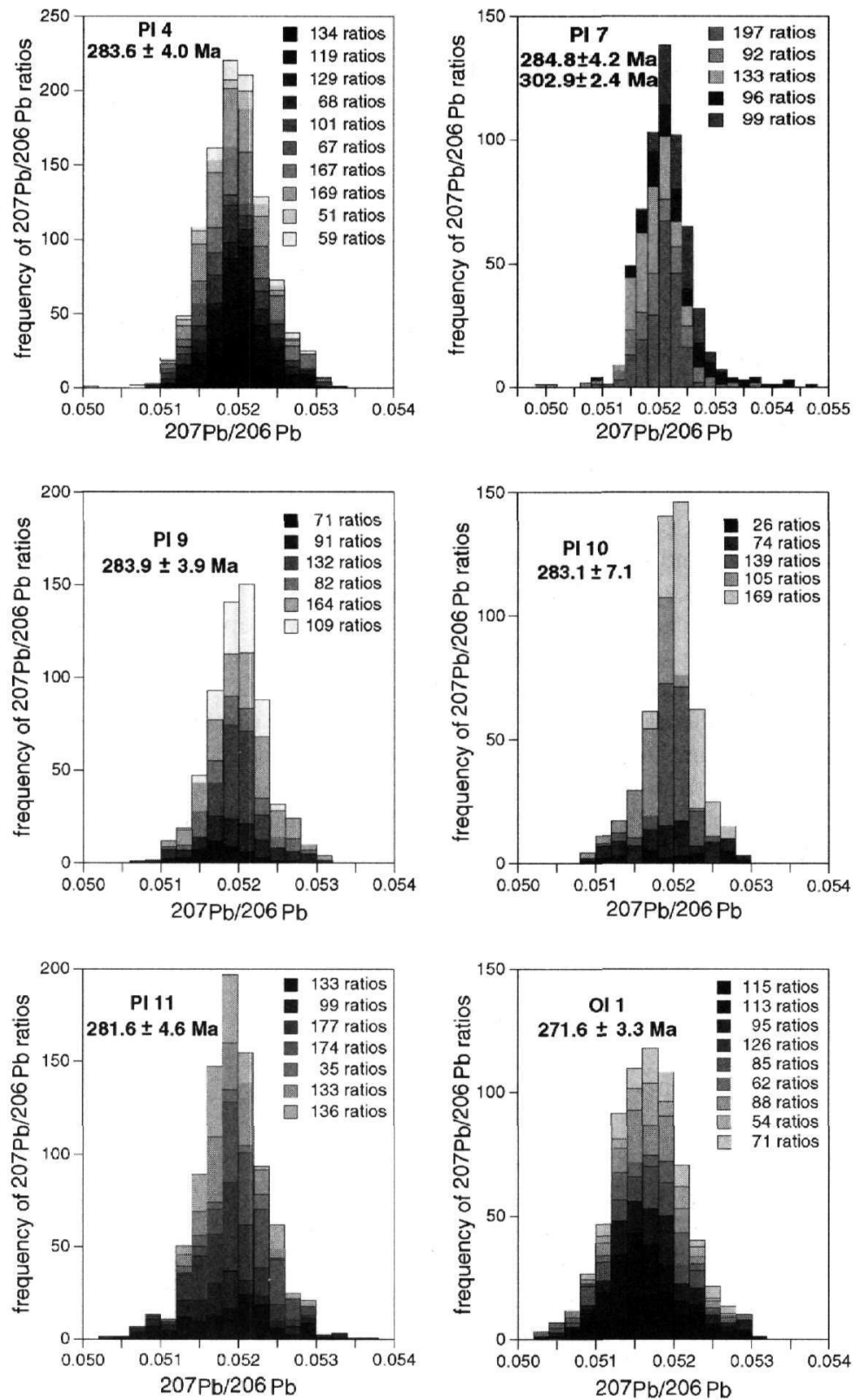

Figure 2. Histogram showing the individual ${ }^{207} \mathrm{~Pb} /{ }^{206} \mathrm{~Pb}$ single zircon analyses for the samples from the central Pelagonian zone. 
chlorite. The sample location implies that this sample belongs to the basement gneisses.

The zircon population is homogeneous in appearance with euhedral grains up to $0.6 \mathrm{~mm}$ in size. These grains are long-prismatic, pink and mainly clear, with only a few grains being turbid. The ages of the zircons from this sample do not, however, form a homogeneous population. Most of the ages cluster in a narrow interval from 276.3287.3 Ma with a mean age of 283.9 $\pm 3.9 \mathrm{Ma}$. Two older grains were discerned with ages of 302.5 and $327.2 \mathrm{Ma}$ respectively. By analogy to sample PL-7 we conclude that these ages either represent mixed ages between the 283.9 Ma event and a much older zircon source, or an early Pelagonian magmatic pulse. One grain yielded an age of 243.8 \pm 7.1 Ma, which might reflect $\mathrm{Pb}$ loss during a Triassic event or a diffusive $\mathrm{Pb}$ loss without age significance.

Sample PL-10 was collected $4 \mathrm{~km}$ east of Olympiada village (Fig. 1). This sample shows a schistose fabric due to pervasive foliation. Small, centimetre-sized kink folds suggesting the onset of crenulations fold the foliation itself. Despite the intense deformation, an igneous origin can still be assigned to the rock. The schist is of dioritic composition and consists of elongated feldspars and quartz, amphibole, biotite and chlorite. It is greenish in colour due to the low grade alteration that accompanied deformation. This rock is part of the basement gneisses according to the geological map of Greece (IGME, 1983).

The zircons of this sample are euhedral, clear or slightly turbid, and up to $0.4 \mathrm{~mm}$ in size. Their colour is pink and their habit is long-prismatic and bi-pyramidal. The ages of the zircons from this sample vary between $174.0 \mathrm{Ma}$ and 324.3 Ma. The majority of the zircons are close together with a mean age of $283.3 \pm 7.1 \mathrm{Ma}$. We interpret this age as the igneous formation age of the diorite. The grains yielding older ages, around ca. $320 \mathrm{Ma}$, are again interpreted as inherited grains of an older magmatic phase, and the $174 \mathrm{Ma}$ age as due to secondary $\mathrm{Pb}$ depletion.

Sample PL-11 was taken from a locality $2 \mathrm{~km}$ east of PL-10 on the road to Kriovrisi, about $800 \mathrm{~m}$ above sea level (Fig. 1). The sample is similar to PL-10 but more strongly deformed and the original igneous texture is difficult to recognize. Apart from its pervasive schistosity, a second deformation is suggested by the development of crenulations. The minerals that can be identified are quartz, feldspars, chlorite and blue amphibole. The colour of the rock specimen is bluish-green or light-brownish on foliation planes due to the occurrence of iron hydroxides. According to the geological map of Greece (IGME, 1983), this rock belongs to the Ambelakia unit proper.

The zircons are euhedral, pink, long-prismatic, clear or turbid and up to $0.5 \mathrm{~mm}$ in size. The ages of the zircons range between 278.9 and $418.9 \mathrm{Ma}$. We consider the mean age of $281.6 \pm 4.6 \mathrm{Ma}$ as the igneous formation age, whereas that of $418.9 \mathrm{Ma}$ as an indication of zircon inheritance.

Sample OL-1 was collected at $1800 \mathrm{~m}$ above sea level on the SW slopes of Mt. Olympos (Fig. 1; see Avgerinas, 1999 for details). It is a weakly-deformed, medium-grained granodiorite with quartz, feldspars, amphibole, and biotite as major constituents. Chlorite is the main alteration product.

The zircons are pink, euhedral, up to $0.5 \mathrm{~mm}$ in size and mainly turbid; only a few grains are clear. The ages scatter between $226.2 \pm 4.8$ and $999 \pm 2.0 \mathrm{Ma}$. The majority is grouped around a mean value of $271.6 \pm 3.3 \mathrm{Ma}$, which appears to date the intrusion age. A second small group of values is around $286.6 \pm 4.6 \mathrm{Ma}$. Secondary $\mathrm{Pb}$ loss is indicated by values of $226.2 \pm 4.8 \mathrm{Ma}$ and $253.9 \pm 6.5 \mathrm{Ma}$. Some older, probably also inherited grains have ages of 324.7, 438.8, 452.2, and even $999.1 \mathrm{Ma}$. The scattering of ages obtained for this sample indicates that the intrusion is slightly younger compared to the other granites studied here, and that it incorporated material from other plutons.

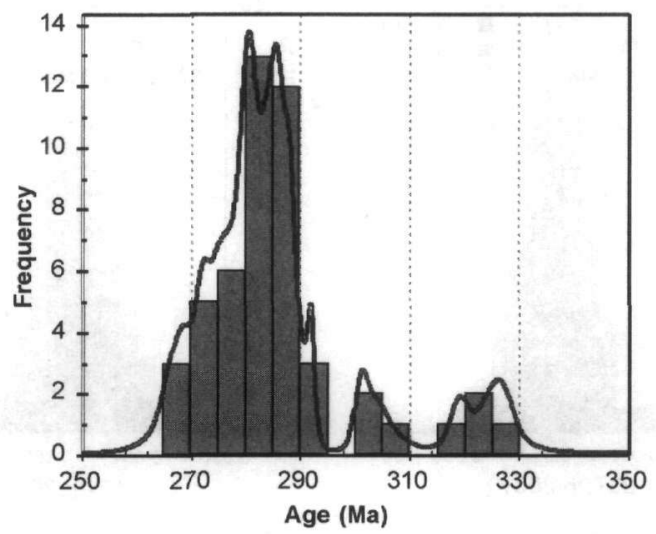

Figure 3. Histogram showing the age distribution of the analysed samples from the Late Carboniferous to Early

Permian (330-260 Ma). Curve after Ludwig (1999). 


\section{DISCUSSION AND CONCLUSIONS}

The rocks examined in the present study are geochemically classified as granodiorites and granites. They are peraluminous with an $\mathrm{A} / \mathrm{CNK}$ value $>1$, and display similarities to I and S-type granites respectively. They are characterized by low HFSE concentrations with $\mathrm{Nb}<15 \mathrm{ppm}$ and $\mathrm{Zr}<206 \mathrm{ppm}$. Such properties are typical of magmatic arc rocks formed in an active continental margin environment. Therefore, the geochemical composition of the granites and gneisses analysed in this study and in other regions of the Pelagonian Zone and the Attic-Cycladic Massif is similar to that of granites from modern active continental margins. Although certain Pelagonian granites had been interpreted as extension related (Kotopouli et al. 2000) the majority of these rocks have strong affinities to granites from convergent plate boundaries.

Investigation of the morphologies and the internal structures of the zircons underscore their igneous origin. Metamorphic zircon growth was not documented in our study. Consequently, the interpretation of the zircon ages as intrusion ages is justified. It should be noted that the zircons from the different localities preserved their age information despite Alpine deformation, metamorphism and secondary alteration.

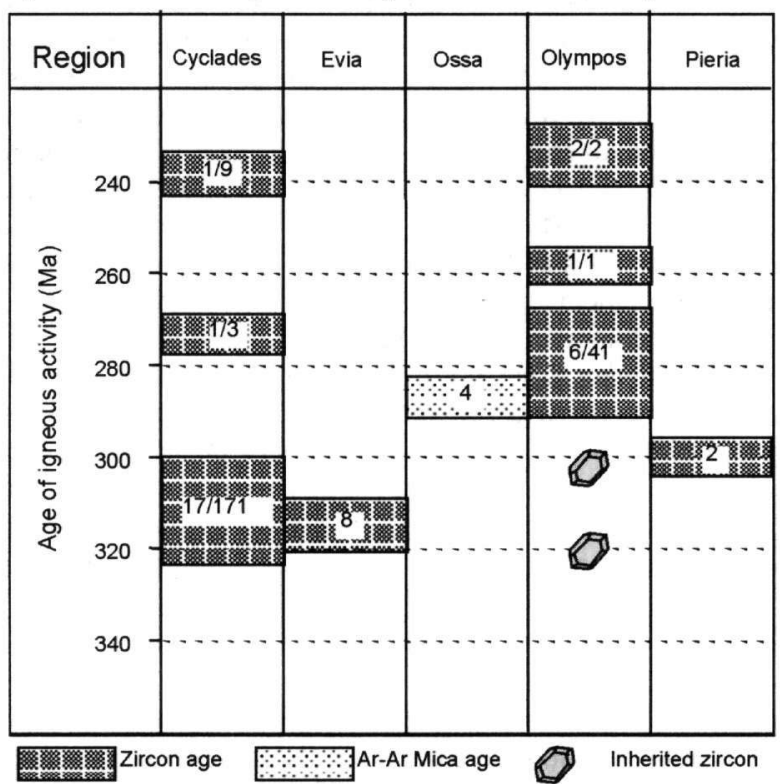

Figure 4. Distribution of igneous formation ages for the various parts of the Pelagonian Zone and the AtticCycladic Massif, with data sources (Yarwood \& Aftalion 1976, Mountrakis 1983, De Bono 1998, Engel \& Reischmann 1998, 2001, and Reischmann 1998). Numbers in boxes: number of samples / zircon grains analysed.

The crystalline basement ages obtained from zircons in this study bear some important implications for the evolution of the Pelagonian Zone. One of these implications concerns the age relations between the different rock units according to previous subdivisions (Schmitt 1983, Schermer 1993). Since all dated samples collected west of Mt. Olympos yield, within error, identical ages, there is no reason to assume that they belong to different units. The only difference between the rocks is the degree of deformation. Igneous formation for this part of the basement is therefore constrained to $280-290 \mathrm{Ma}$ (Fig. 3). The asymmetry of the major peak on the age distribution curve is caused by the relatively younger age (271.6 Ma) of the Mt. Olympos sample OL-1. The inherited grains indicate two minor peaks at 300-310 Ma and around 320Ma (Fig. 3), similar to the age distribution seen in other regions of the Pelagonian Zone and the Attic-Cycladic Massif (Fig. 4). The ages of the inherited grains might be explained by early Pelagonian, (i.e. Late Carboniferous) granites that were subsequently intruded, or partly digested, or remelted by Early Permian granites. The even older zircons have been inherited from a hitherto unknown older source. A minor group of zircons indicates a Triassic age. This is not unique to the Olympos region but is also known from the Cyclades (Keay 1998, Reischmann 1998). We tentatively suggest that this age has a geological significance and might indicate a Triassic event, which can be related to an extensional regime as proposed by Pe-Piper (1997).

If we interpret all mean ages as igneous formation ages, this would imply that all rocks belong to the same 
unit. This unit had undergone variable deformation that obscured the igneous appearance of the rocks and, to some extent, affected their chemical compositions. We propose that subdivision of the Pelagonian Zone into gneisses, granites and the Ambelakia unit is no longer appropriate, at least for our study area (see also Pe-Piper et al. 1993b).

The samples we analysed were collected along a SW-NE profile from Verdikoussa village to Mt. Olympos. We see a general increase in the degree of deformation towards the east with the strongest deformation seen in sample PL-11, which is close to the Olympos marbles and according to previous subdivisions would have been assigned an Ambelakia unit origin. All rocks analysed here are granitic-granodioritic in composition despite their variable deformation. Their chemistry is largely similar and their zircons are almost identical in terms of morphology, colour and age. We therefore interpret sample PL-11, and consequently the Ambelakia unit, as part of the basement unit. This basement consists of granites, which are variably deformed to gneisses and thrusted over the Olympos autochthon. The highest degree of deformation is at the base of the nappe (e.g. PL11) where the granites had been severely overprinted and their igneous texture almost completely erased. Similar observations to the above were made by Lips (1998) for the western flank of Mt. Ossa. If we correlate the two tectonic windows of Olympos and Ossa, the interpretation is straightforward: the basement is a nappe, which appears complex because of the variable deformation. This complexity only reflects the heterogeneity of the deformation that affected various parts of the rather homogeneous granitic basement in different ways.

If we interpret the entire Pelagonian and the Attic-Cycladic Massif as a magmatic arc, then regional variations in the magmatic activity can be seen along strike. In the southern part of this arc, in the Cyclades area, the majority of ages lie between 300 and $320 \mathrm{Ma}$ (Fig. 4). This also applies to Evia Island (De Bono 1998). In the central Pelagonian Zone around Mts. Ossa and Olympos, the $300 \mathrm{Ma}$ age is documented only in inherited grains from this study, while the prevailing igneous phase occurred at ca. 270-290 Ma (Lips 1998 and this study). This implies a shift in magmatic activity along the arc from Late Carboniferous in the south to Early Permian in the north. In the very north of the Pelagonian Zone only a few zircon data are available which do not permit further speculation about timing of magmatic activity. It is, however, clear from the age data available that any attempt at a geodynamic reconstruction of the central Pelagonian must include an ocean on one side of the Pelagonian Zone for a period that lasted at least $30 \mathrm{Ma}$. Final closure of this ocean is unlikely to have taken place before the end of the arc activity, i.e. before ca. $270 \mathrm{Ma}$. Zircon ages similar to those of the Pelagonian-Attic-Cycladic magmatic arc (i.e. 320-270 Ma) have been obtained for orthogneiss samples from the Rhodope Massif in southern Bulgaria (319-305 Ma; Peytcheva \& von Quadt 1995), as well as from NW Turkey (Okay et al. 1996, Фzmen \& Reischmann 1999). Nevertheless, correlations across the Vardar zone should be handled with great care.

\section{REFERENCES}

AVGERINAS, A.V. 1999. Structural evolution of the Mt. Olympos carbonate massif. Unpublished MSc thesis, Aristotle University of Thessaloniki, Greece, 114 p. (in Greek with English summary).

DE BONO, A. 1998. Pelagonian margins in central Evia island (Greece). Stratigraphy and geodynamic evolution. Unpublished $\mathrm{PhD}$ thesis, Lausanne University, $114 \mathrm{p}$.

ENGEL, M \& REISCHMANN T. 1998. Single zircon geochronology of orthogneisses from Paros, Greece. Bull. Geol. Soc. Greece 32/3, 91-99.

ENGEL, M. \& REISCHMANN, T. 2001. Upper Carboniferous magmatism in the central Aegean region: evidence from basement gneisses of the Cyclades. J. Conf. Abs., 5, p. 318.

GODFRIAUX, I. 1968. Étude géologigue de la région de l' Olympe (Grèce). Ann. Geol. Pays Hell. 19, 1-280.

KEAY, S. 1998. The geological evolution of the Cyclades, Greece. Constraints from SHRIMP U-Pb dating. Unpublished $\mathrm{PhD}$ thesis, ANU, Canberra.

KILIAS, A. \& MOUNTRAKIS, D. 1989. The Pelagonian nappe: Tectonics, metamorphism and magmatism. Bull. Geol. Soc. Greece 23/1, 29-46 (in Greek with English abstract).

KILIAS, A. 1995. Tectonic evolution of the Olympus-Ossa mountains: emplacement of the blueschists unit in eastern Thessaly and exhumation of Olympus-Ossa carbonate dome as a result of Tertiary extension (central Greece). Mineral Wealth 96, 7-22.

KOBER, B. 1987. Single-zircon evaporation combined with $\mathrm{Pb}+\mathrm{emitter}$-bedding for ${ }^{207} \mathrm{~Pb} /{ }^{206} \mathrm{~Pb}$-age investigations using thermal ion mass spectrometry, and implications to zirconology. Contrib. Mineral. Petrol. 96, 63-71.

KOTOPOULI, C., PE-PIPER, G. \& PIPER, D.J.W. 2000. Petrology and evolution of the Hercynian Pieria Granitoid Complex (Thessaly, Greece): paleogeographic and geodynamic implications. Lithos 50, 137-152.

LIPS, A.L.W. 1998. Temporal constraints on the kinematics of the destabilization of an orogen; syn- to post-orogenic extensional collapse of the Northern Aegean region. Unpublished $\mathrm{PhD}$ thesis, Utrecht University, $223 \mathrm{p}$. 
LUDWIG, K.R. 1999. Isoplot version 2.1. Berkeley Geochronology Center Special Publication 1a.

MOUNTRAKIS, D. 1983. The geological structure of the northern Pelagonian Zone and the geotectonic evolution of the Internal Hellenides. Habilit. Thesis, Aristotle University of Thessaloniki, Greece, 289 p. (in Greek with English summary).

OKAY, A. I., SATIR, M., MALUSKI, H., SIYAKO, M., MONIÉ, P., METZGER, R. \& AKY1/4Z, S. 1996. Paleo- and Neo-Tethyan events in northwestern Turkey: geologic and geochronologic constraints. In: Yin, A. \& Harrison, T.M. (eds). The tectonic evolution of Asia, Cambridge Univ. Press, 420-441.

ÖZMEN, F. \& REISCHMANN, T. 1999. The age of the Sakarya continent in W. Anatolia: Implications for the evolution of the Aegean region. J. Conf. Abs., 4, 805-806.

PEYTCHEVA, I. \& VON QUADT, A.V. 1995. U-Pb zircon dating of metagranites from Byala-Reka region in the east Rhodopes, Bulgaria. Geol. Soc. Greece, Sp. Publ., 4, 637-642

PE-PIPER, G. 1997. The nature of Triassic extension-related magmatism in Greece: evidence from $\mathrm{Nd}$ and $\mathrm{Pb}$ isotope geochemistry. Geol.Mag. 135, 331-348.

PE-PIPER, G., DOUTSOS, T. \& MPORONKAY, C. 1993a. Structure, geochemistry and mineralogy of Hercynian granitoids rocks of the Verdikoussa area, northern Thessaly, Greece and their regional significance. Neues Jahr. Min. Abh. 165, 267-296.

PE-PIPER, G., DOUTSOS, T. \& MIJARA, A. 1993b. Petrology and regional significance of the Hercynian granitoids rocks of the Olympiada area, northern Thessaly, Greece. Chem. Erde 53, 21-36.

REISCHMANN, T. \& ANTHES, G. 1996. Geochronology of the Mid German Crystalline Rise west of the River Rhine. Geol. Rundschau 85, 761-774.

REISCHMANN, T. 1998. Pre-Alpine origin of tectonic units from the metamorphic complex of Naxos, Greece, identified by single zircon $\mathrm{Pb} / \mathrm{Pb}$ dating. Bull. Geol. Soc. Greece 32/3, 101-111.

SCHERMER, E. 1993. Geometry and kinematics of continental basement deformation during the Alpine orogeny, Mt. Olympos region, Greece. J. Struct. Geol. 15, 571-591.

SCHMITT, A. 1983. Nouvelles contributions à l' étude géologique des Pieria, de l'Olympe et de l'Ossa (Grèce du Nord). Unpublished PhD thesis, Mons University, Belgium, $400 \mathrm{p}$.

STACEY, J.S. \& KRAMERS, J.D. 1975. Approximation of terrestrial lead isotope evolution by a two-stage model. Earth Planet. Sci. Lett. 26, 207-221.

STEIGER, R.H. \& JÄGER, E. 1977. Subcommission on geochronology: Convention on the use of decay constants in geo- and cosmochronology. Earth Planet. Sci. Lett. 36, 359-362.

VERGÉLY, P. \& MERCIER, J. 1990. La fenêtre métamorphique de l' Olympe (Macédoine, Grèce); Compression et extension cénozoïques. Bull. Soc. géol. France 18, 819-829.

YARWOOD, G.A. \& AFTALION, M. 1976. Field relations and U-Pb geochronology of a granite from the Pelagonian zone of the Hellenides (High Pieria, Greece). Bull. Soc. Geol. France 7, 259-264. 